\title{
THE DESCRIPTION AND COMPARISON OF BUDGET SYSTEMS: THE CASE OF TURKEY (1924-2018)
}

\author{
Haydar Lütfü EJDER ${ }^{1}$
}

\author{
Melek Sena CANGIR ${ }^{2}$
}

\begin{abstract}
The budget is an important economic policy tool for policy-makers, as well as its classical functions. Countries choose of budget systems according to their political, economic and social aspects is important in terms of economic, effective and efficient use of public resources. In this study, the positive and negative aspects of budgetary systems are specified and they are compared on the basis of performance criteria. In this context, the actual budget system changes in Turkey were examined whether they are Assoc.d with budget deficits, growth and unemployment. Examination of the tables created from time series of the mentioned macro variables, It was concluded that there was a parallelism between the system changes and budget deficits, system canges were followed by an increase in extra-budgetary expenditures while there was no noticeable relationship with the other two variables.
\end{abstract}

Keywords: Budget, Budget Systems, Comparison of Budget Systems, Performance Criteria

JEL Code: H61, H62.

\section{Introduction}

Budget is the main tool for the control, management, and production of interactions between macro-level financial instruments and institutional financial instruments. The budget system that is compatible with the political, social, economic and financial structure not only forms the macroeconomic and institutional financial instruments in that direction but also ensures the economic, effective and efficient use the public resources. In this study, budget systems used in Turkey and the necessity of using them is explained by pointing to the positive and negative aspects of these systems. Additionally, the impact of the budget system changes on macro economic variables and on the financial control as a whole is analysed.

Budget systems, respectively, are presented as the traditional budget system, performance budget system, program budget system, planning-programming-budgeting system.

\section{Budget Systems}

Budget system is an important tool that both forms the preparation, implementation, and control of the budget and ensures the system efficiency as a whole. Additionally, budget systems have emerged and diversified within the development process of the economy in accordance with the demand of the society from the state. (Bülbül vd., 2005: 56)

\footnotetext{
1 Asst. Prof., Ankara Hacı Bayram Veli University, haydar@gazi.edu.tr

2 Graduate Student, Ankara Hacı Bayram Veli University, Department of Finance.
} 


\subsection{Traditional Budget System}

Traditional budget system has two important elements. The first one is concerned with which resources are allocated to which expenditure unit while the second one is related to the administrative dimension of spending process. As the grants are given at the unit level, these budgets are also called the "organization budgets". In the literature, the name "expenditure items budget" is also used. The focus of the traditional budget system is on the amount that is to be spent. The logic behind and expected benefits of the expenditures on the other hand is not taken into account. (Tüğen, 2007: 107)

Table 1. Advantages And Disadvantages Of Traditional Budget System

\begin{tabular}{|l|l|}
\hline \multicolumn{2}{|c|}{ Traditional Budget System } \\
\hline Advantages & Disadvantages \\
\hline It provides a framework of control & Disconnection from strategic plan \\
\hline Makes it easier to manage activities & Causes waste \\
\hline Functional & Causes inefficiency in resource allocation \\
\hline It accommodates the need to decentralise & Low change responsiveness \\
\hline Annual forecast is easy & Doesn't encourage innovation \\
\hline Provides stability & Repeats incorrect estimates \\
\hline Provides consistency & Application causes a loss of time \\
\hline It is part of organisational culture & Performing only financial audit (Account audit) \\
\hline Specialization & Prone to data entry errors \\
\hline
\end{tabular}

Source: TRG International,How To Create An Advanced Budgeting System, 2009:5-6. (Compiled by author.)

\subsubsection{Traditional Budget System: The Case of Turkey [1924-1972]}

Turkish public financial management to a large extend depends on law no 1050 which dates back to the beginning of the Republic of Turkey. This law, which entered into force in 1927, was implemented with very few amendments near to eighty years. However, over time, especially after 1980s, rapid changes in economic and social economic areas made it necessary to reconsider the public financial management system. The budget deficits during 1970 s ve 1980 s is one of the clearest indicator of this fact.

Graphic 1. Consolidated Budget Income, Expense and Balance [1924-1972]

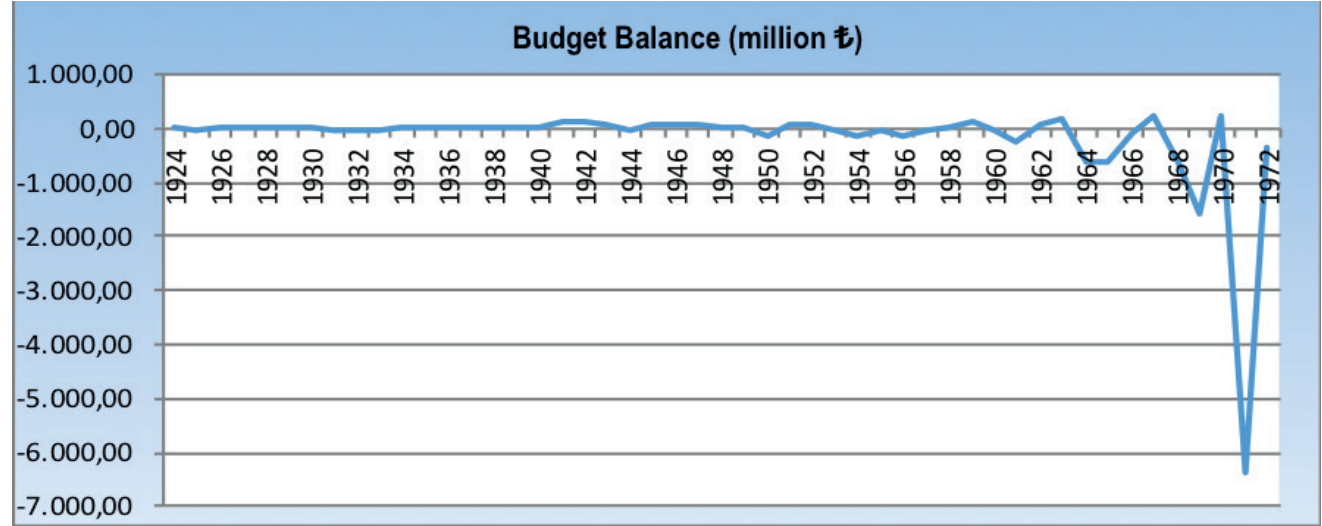

Source: BÜMKO Statistics, 2018. 


\subsection{Performance Budget System}

The priority of performance (business) budget is on the way a public service is performed, while on the macro level it aims to increase efficiency in public administration.

The performance budget focuses on what government does and achieve, rather than what it buys. Thus, the benefits earned or provided from a particular expense is important. Expenses that serve specific purposes in the performance budget are collected in the same programs and the costs and benefits of each program are calculated. The value of the performance budget comes from the fact that it is a management tool. It is a tool that administrators can use to ensure efficiency and effectiveness. (Edizdoğan, 2004: 388).

Table 2. Advantages and Disadvantages of Performance Budget System

\begin{tabular}{|l|l|}
\hline \multicolumn{2}{|c|}{ Performance Budget System } \\
\hline Advantages & Disadvantages \\
\hline Clear purpose & Subjective \\
\hline $\begin{array}{l}\text { It becomes easier to assess the performance and } \\
\text { correct the deviations }\end{array}$ & $\begin{array}{l}\text { Monetary value of social projects is difficult to } \\
\text { calculate }\end{array}$ \\
\hline Transparency is in the foreground & Costs may vary from institution to institution \\
\hline It helps to increase the accountability & Need a strong evaluation system \\
\hline Performances are evaluated periodically & $\begin{array}{l}\text { The performance budget requires a strong } \\
\text { system of accounting }\end{array}$ \\
\hline Performance measurement based on outputs & $\begin{array}{l}\text { The reporting system needs to be accurate } \\
\text { and complete }\end{array}$ \\
\hline Performance measurement is subjective & There is a possibility of changing the data \\
\hline Improvement in performance & $\begin{array}{l}\text { Existence of implementation difficulties in } \\
\text { long-term projects }\end{array}$ \\
\hline Efficiency-oriented & $\begin{array}{l}\text { It makes difficult to measure the results of the } \\
\text { projects in long-term }\end{array}$ \\
\hline
\end{tabular}

Source: Efinancemanagement- Budgeting- Performance Budget, 2018. (Compiled by author.)

The experimentation with and experience of performance budgeting are wide ranging. Because performance budgeting develops at various stages in terms of how performance information is used in the budgeting process, this chapter distinguishes performance budgeting in four categories:

Performance-reported budgeting (PRB) presents performance information as part of thebudget documentation, but budgetary actors do not use itfor resource allocation.

Performance-informed budgeting (PIB) refers to a budgeting process that takes program performance into account but uses the information only as a minor factor in making decisions.

Performance-based budgeting (PBB) implies that performance information plays an important role for resource allocation, along with many other factors,but does not necessarily determine the amount of resources allocated. 
Performance-determined budgeting (PDB) means that allocation of resources is directly and explicitly linked to units of performance (Shah \& Shen, 2007: 153).

\subsubsection{Transition Process to Performance Budget System: The Case of Turkey [1973-2005]}

Performance-based budgeting was introduced in Turkey in 2006 with the law numbered 5018. Looking at macro variables such as budget balance, growth, and unemployment can a connection be observed between the system change and the performance of these variables? In that connection what is seen in the data is the rise of the budget deficit just before the system change. (See Chart 6. Consolidated Budget Income, Expense, and Balance (1973-2005)

However, there seems to be no discernable correlation between the system change and the other variables.

\subsubsection{Performance Budget System: The Case of Turkey [2006-2018]}

Performance based budgeting was put into effect within the framework of the following principles:

- Determination of measurable targets in accordance with the policies set out in Law No. 5018.

- Calculating the cost of the identified targets (resource allocation).

- Providing administrative and financial flexibility to managers and organizations in achieving the targets.

- Monitoring the results by taking into consideration the targets set at the beginning.

It appears that performance-based budgeting is intended to ensure efficiency both at resource allocation and resource utilization level together.

Graphic 2. Central Government Budget Income, Expense and Balance [2006-2018]

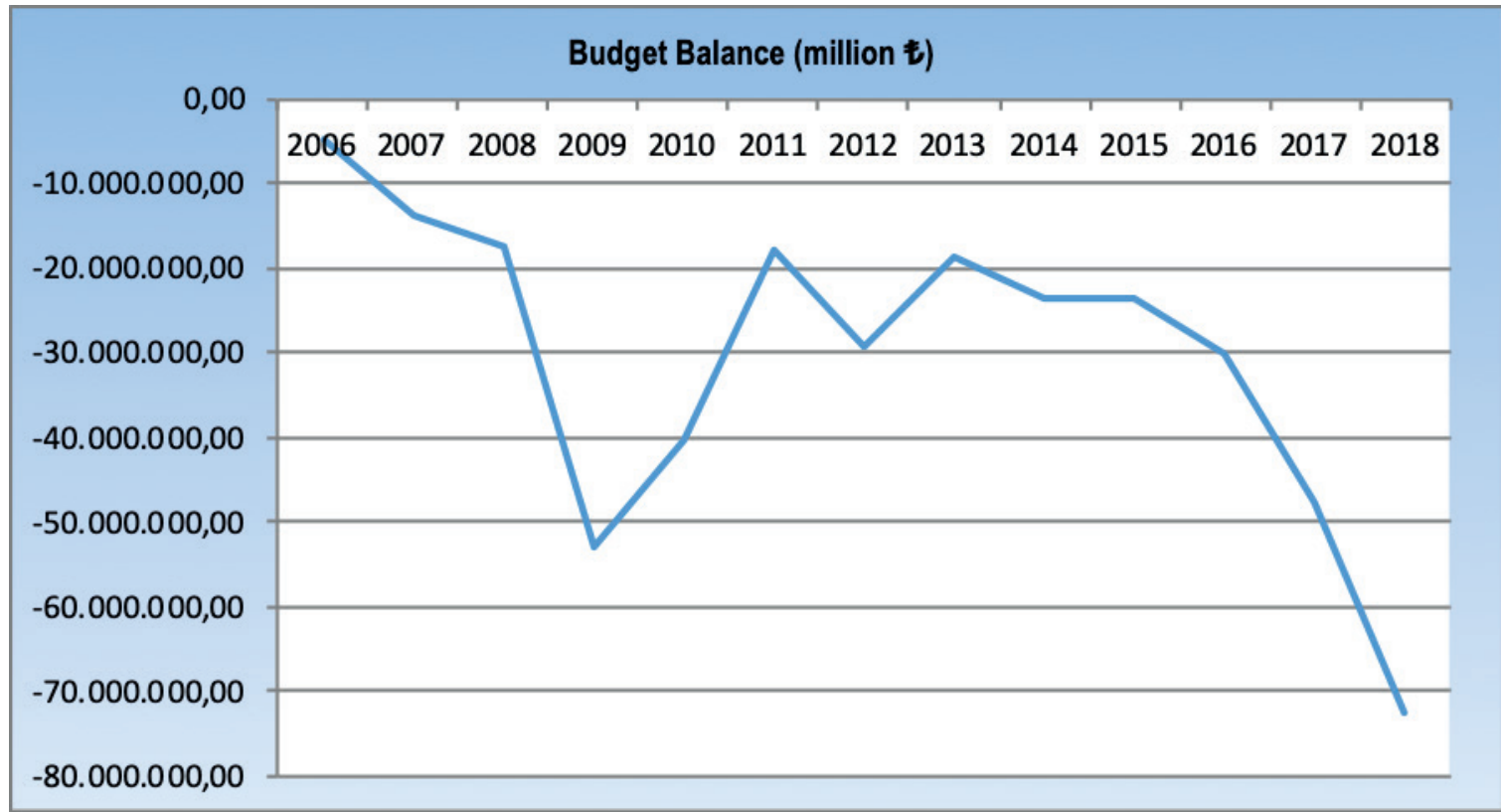

Source: BÜMKO Statistics, 2018. 


\section{Graphic 3. Turkey Gross Domestic Product [2006-2016] (US \$ Capita)}

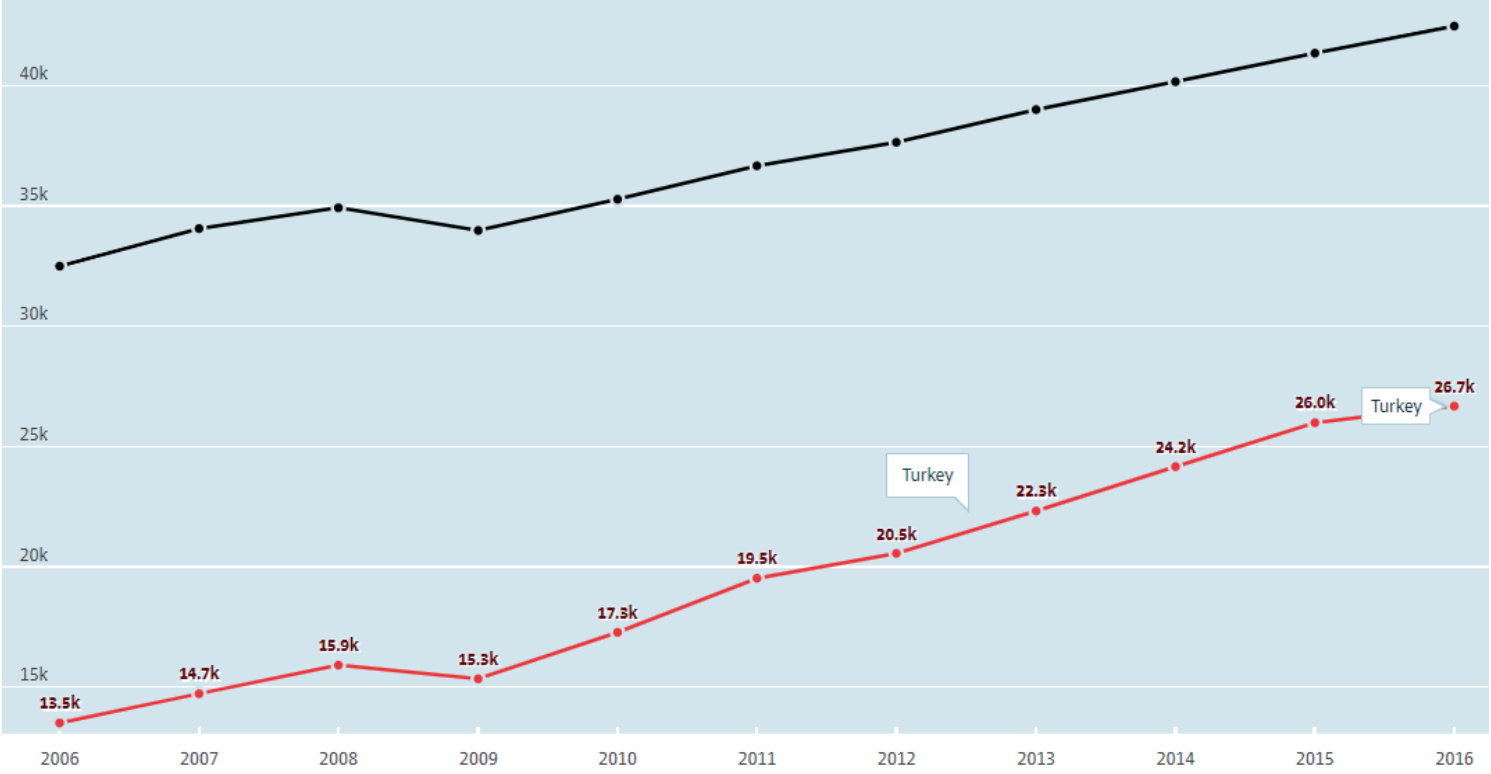

Source: OECD Data, 2016: https://data.oecd.org/gdp/gross-domestic-product-gdp.htm\#indicatorchart *Data were calculated using purchasing power parity

\section{Graphic 4. Turkey Annual Growth Rates (\%) [2006-2017]}

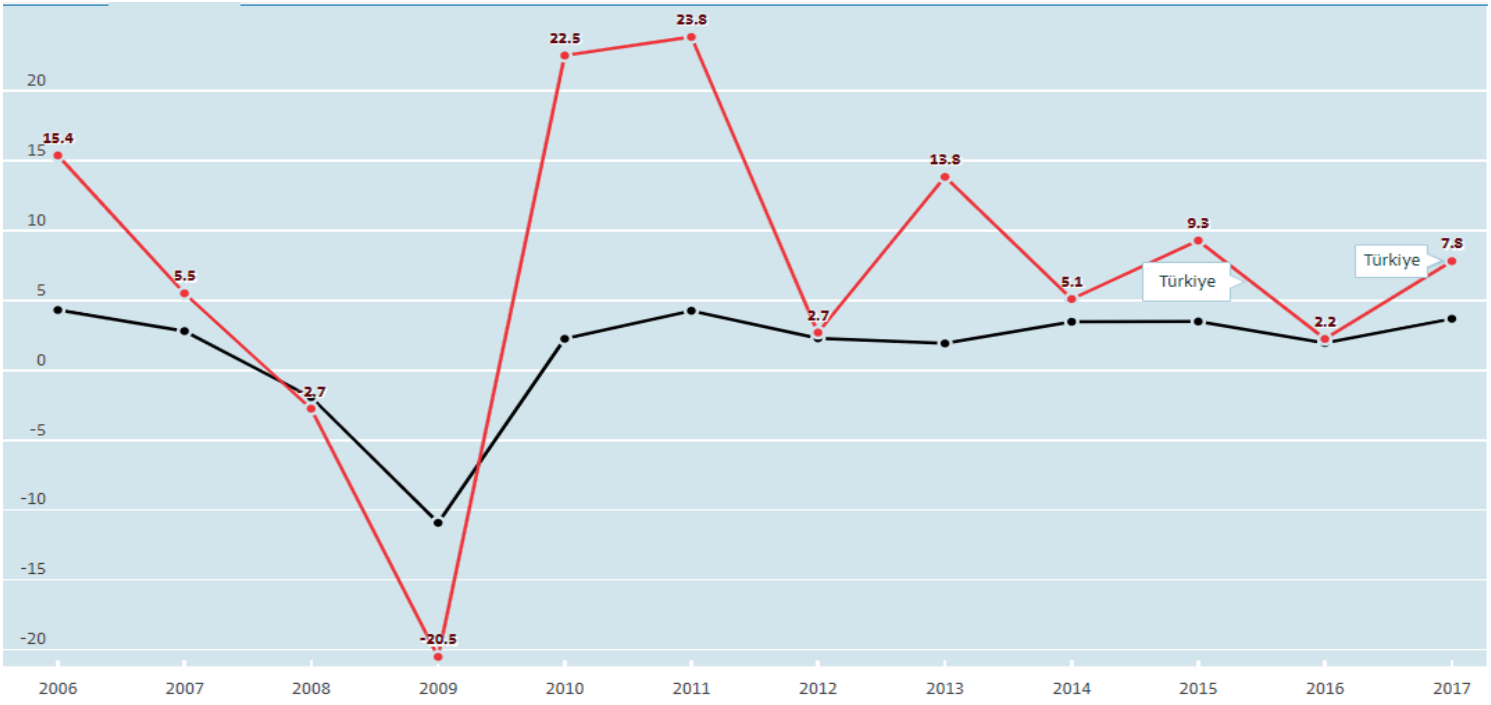

Source: OECD Data, 2016: Growth rates are composed of investment expenditures. https://data.oecd. org/fr/gdp/investissement-fbcf.htm 
Graphic 5. Turkey Unemployment Rate (\%) [2006-2017]

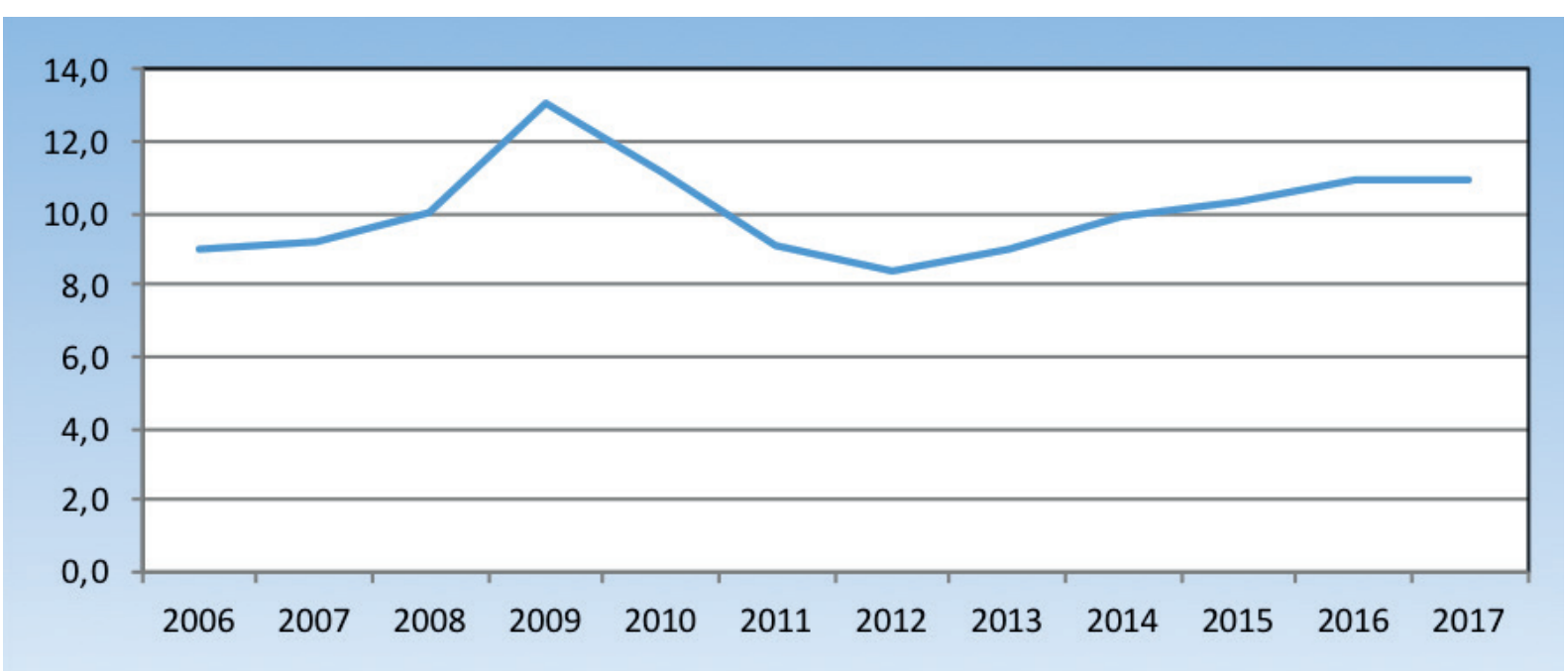

Source: TÜiK, Labor Force Statistics 2017:https://biruni.tuik.gov.tr/isgucuapp/isgucu.zul

As regard to effect of the system change on the macroeconomic variables during that period, the following observations are in order:

The first significant deterioration in the budget balance was realized in 2009. The deterioration trend, which started again in 2013, continued until 2018, which is the last year with realized data. The striking point here is that the worsening of the budget balance was accompanied by the transition to the program-based performance-based budget system in 2017-18.

There is no discernible relationship between changes in the budget system and other data.

\subsection{Program Budget System}

Program budget aims, in addition to performance, also to determine what is to be done optimally in terms of cost and welfare. 
Table 3. Advantages and Disadvantages of Program Budget System

\begin{tabular}{|c|c|}
\hline \multicolumn{2}{|c|}{ Program Budget System } \\
\hline Advantages & Disadvantages \\
\hline Makes priority rankings & Late adaptation to changes \\
\hline Reduces costs & $\begin{array}{l}\text { It is difficult to adapt resource changes to } \\
\text { the budget }\end{array}$ \\
\hline Prevents waste & $\begin{array}{l}\text { Changes in spending may cause budgeting } \\
\text { of double spending }\end{array}$ \\
\hline $\begin{array}{l}\text { Gives management and responsibility to all levels } \\
\text { of the institution }\end{array}$ & $\begin{array}{l}\text { Multiple layers of administrators govern a } \\
\text { project }\end{array}$ \\
\hline Encourages innovation & Decision-making is difficult \\
\hline Incorrect estimates do not repeating & $\begin{array}{l}\text { Idea differences can prolong the decision } \\
\text { process }\end{array}$ \\
\hline $\begin{array}{l}\text { Ensures efficiency and effectiveness in resource } \\
\text { allocation }\end{array}$ & It causes a loss of time \\
\hline Adds accountability to the organization & Difficult to measure costs \\
\hline Allows performance measurement & $\begin{array}{l}\text { The performance of the project is difficult to } \\
\text { assess }\end{array}$ \\
\hline
\end{tabular}

Source: Program Budget, 2018. (Compiled by author.)

In that connection it rankes the targets that are determined by the public authorities. For that reason, programs and sub-programs are made on the basis of activities/projects. This hierarchical program structure covers also the classification of analytical budget.

\subsubsection{Transition Process to Program Budget System: The Case of Turkey [1924-1972]}

It is possible to make the following conclusion regarding the consolidated budget balance during the period of 1924-1972: Until 1967, it followed a relatively stable course. However, after 1967, a visible deterioration is observed. On the other hand, at the beginning of the 1970s transition to program budget had started. This seems to suggest that there may be a correlation between deterioration in the budget balance and the attempts to change the system (See Chart 1. Consolidated Budget Income, Expense, and Balance [1924-1972]).

\subsubsection{Program Budget System: The Case of Turkey [1973-2005]}

In 1973, the program budged was adopted and the traditional budget system was repealed. The aim behind of this system change was to establish a link between the budget and the development plans and as a result to facilitate monitoring of objectives of the plans (BÜMKO, Türkiye'de Bütçeleme). 
Graphic 6. Consolidated Budget Income, Expense and Balance [1973-2005]

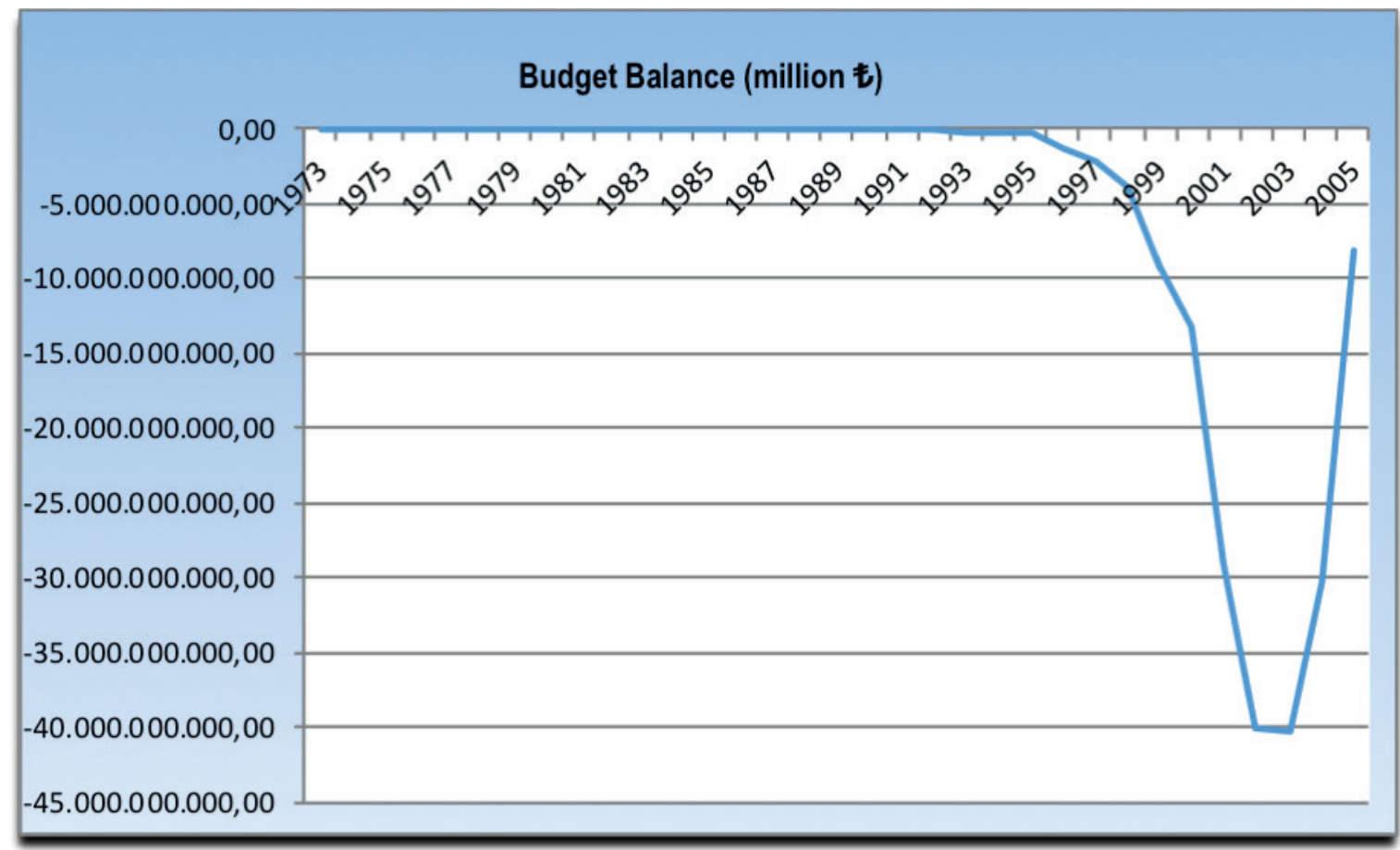

Source: BÜMKO Statistics, 2018.

\section{Graphic 7. Turkey Gross Domestic Product [1973-2005] (US \$ / Capita)}

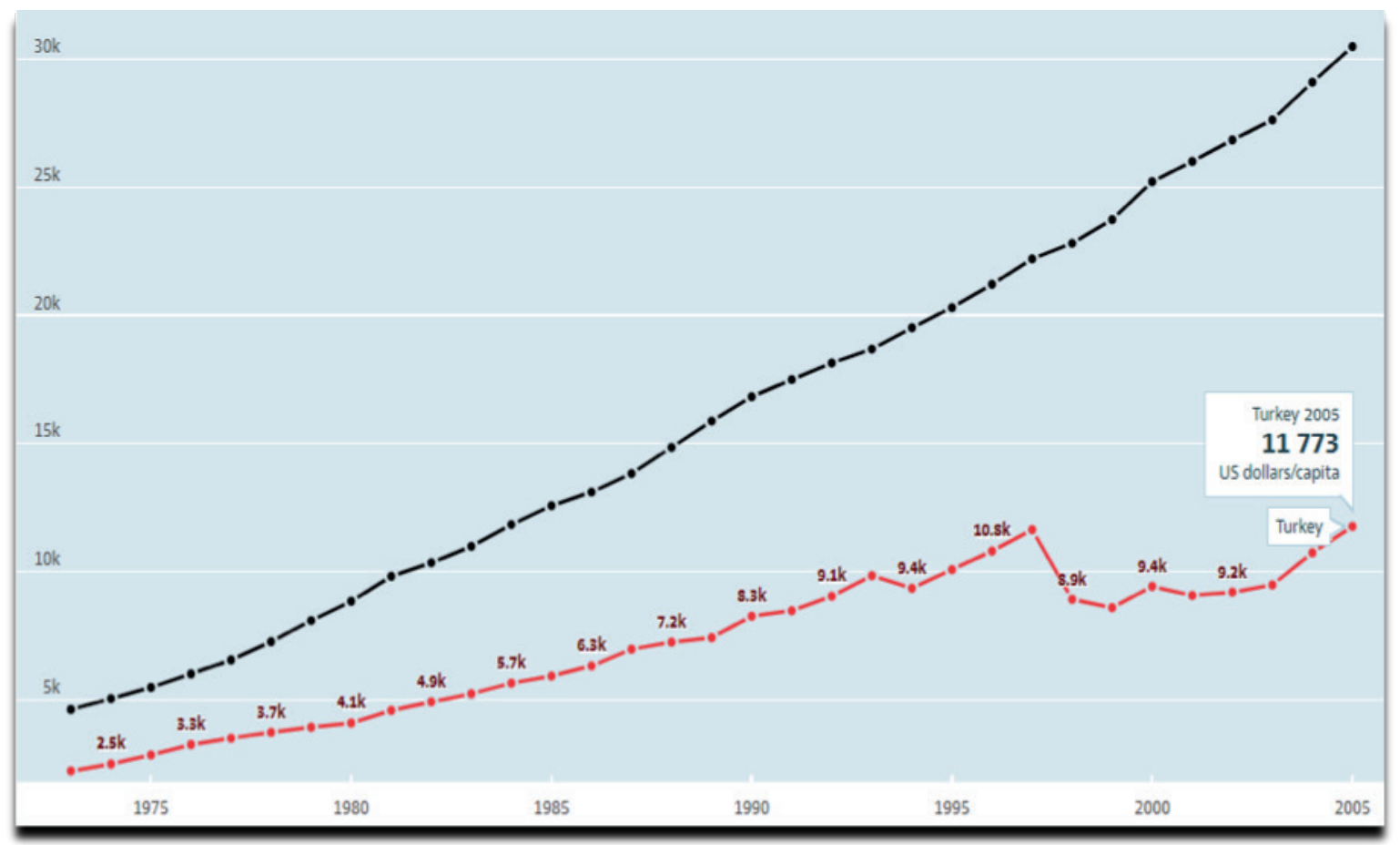

Source: OECD Data, 2016: https://data.oecd.org/gdp/gross-domestic-product-gdp.htm\#indicator-chart

* Data were calculated using purchasing power parity. 
Graphic 8. Turkey Annual Growth Rates (\%) [1973-2005]

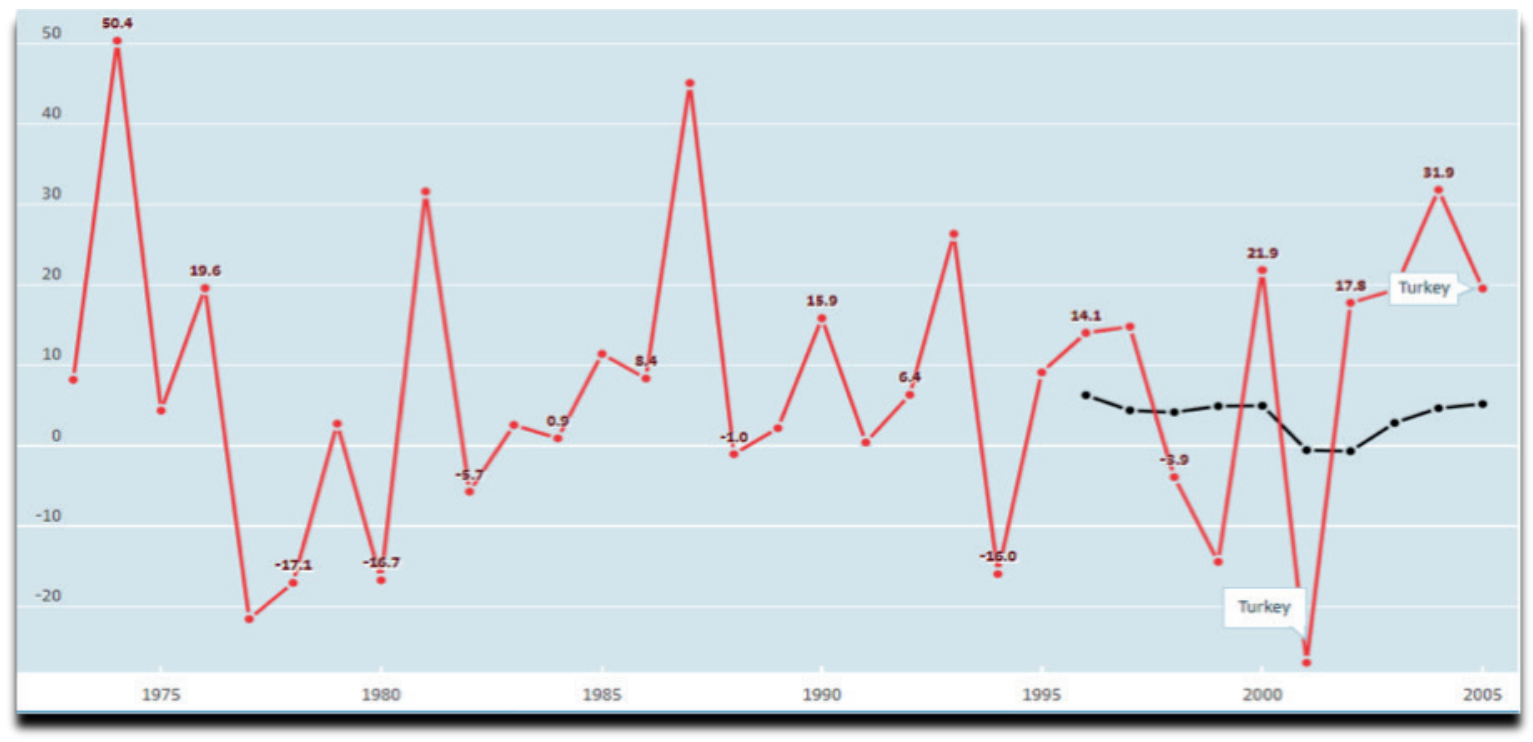

Source: OECD Data, 2016: Büyüme oranları, yatırım harcamaları kaleminden oluşturulmuştur. https://data. oecd.org/fr/gdp/investissement-fbcf.htm

During the implementation of the program budget period, the worst performance in terms of budget balance was recorded in 2003-2004. Performance based budget system, on the other hand, was put into effect in 2006. This point, which may imply a possible correlation, has already been noted.

\subsection{Planning-Programming-Budgeting System (PPBS)}

PPBS is a more comprehensive form of performance and program budget within modern budget systems and is based on coherence between planning and budgeting. Considering the planning, programming and budgeting stages, the stages must be in order and the causal link between them should be present. 
Table 4. Advantages and Disadvantages of Planning-Programming Budgeting System

\begin{tabular}{|l|l|}
\hline \multicolumn{2}{|c|}{ Planning-Programming Budgeting System } \\
\hline Advantages & Disadvantages \\
\hline Fully compliant with the democracy & Not in full accord with the legislation \\
\hline $\begin{array}{l}\text { Supports decision-making process of } \\
\text { executives }\end{array}$ & It's hard to write what is the best alternative \\
\hline Can be used in all decision processes & $\begin{array}{l}\text { Budget prepation process is difficult to harmonize } \\
\text { with law }\end{array}$ \\
\hline Creates a sense of responsibility & Easy to glimpse at, but hard to master \\
\hline Easy to set up source-result relationship & Depends greatly on good operation \\
\hline Pragmatism (mission oriented) & Big and complex \\
\hline It can help reducing casualties & Labor intensive \\
\hline Flexibility in optimization & $\begin{array}{l}\text { Although it is theoretically perfect system, it is not } \\
\text { true (Completely tied to Money) }\end{array}$ \\
\hline Great for forecasting & $\begin{array}{l}\text { Has not yet have the chance to actually prove its full } \\
\text { potential in huge scale conflicts }\end{array}$ \\
\hline
\end{tabular}

Source: Ursoiu, A.B., 2010:101-109 (Compiled by author.)

\subsubsection{Planning-Programming and Budgeting System (PPBS): The Case of Turkey}

With adoption of Public Financial Management and Control Law ( law number 5018) in 2003 it was envisaged to establish a more efficient, effective and economic use of public resources. Among the aims was also to establish a link between programs and the budget (BÜMKO, Budgeting in Turkey).

For realization of that aims beginning at the years 2017-2018 works for transition to a program and performance based budget system have started. This work is included in the New Economy Program prepared by the Ministry of Treasury and Finance for the period of 2019-2021.

\section{Comparison of Budget Systems}

In public administration, the use of resources refers to the stages of public input. When budget systems are taken into consideration, there are four performance criteria: cost, input, output, and outcome. 
Figure 1. Performance in context

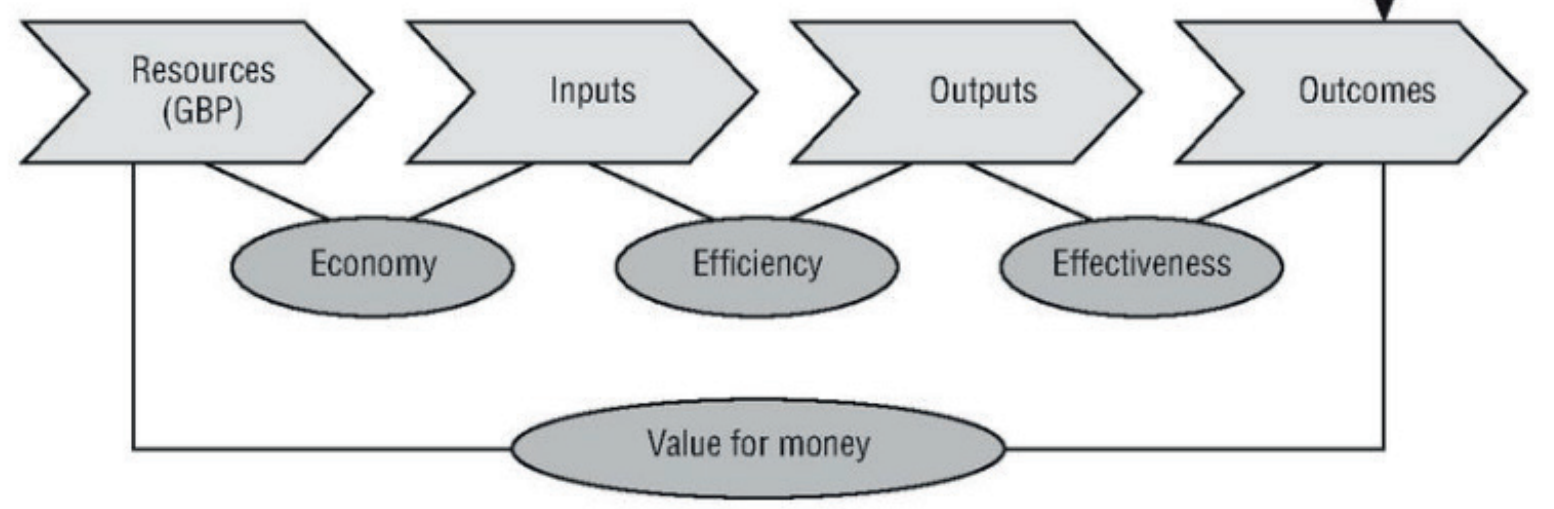

Source: Performance Budgeting in OECD Countries, 2007: 194

Each criterion forms the basis of four different budget systems.

Table 5. Comparison of Budget Systems

\begin{tabular}{|l|l|l|l|l|}
\hline \multicolumn{2}{|c|}{$\begin{array}{l}\text { Traditional } \\
\text { Budget System }\end{array}$} & \multicolumn{1}{l}{$\begin{array}{l}\text { Performance } \\
\text { Budget System }\end{array}$} & \multicolumn{1}{l|}{$\begin{array}{l}\text { Program Budget } \\
\text { System }\end{array}$} & PPBS \\
\hline $\begin{array}{l}\text { Performance } \\
\text { in context }\end{array}$ & Inputs & Resources & Outputs & Outcomes \\
\hline $\begin{array}{l}\text { Use of } \\
\text { Resources }\end{array}$ & $\begin{array}{l}\text { Resource } \\
\text { purchase } \\
\text { expenditures }\end{array}$ & $\begin{array}{l}\text { Resource } \\
\text { purchase } \\
\text { expenditures }\end{array}$ & $\begin{array}{l}\text { Expenditure for } \\
\text { optimal service } \\
\text { output }\end{array}$ & $\begin{array}{l}\text { Expenditures for social } \\
\text { purposes }\end{array}$ \\
\hline Purpose & Audit & Production & Governance & $\begin{array}{l}\text { Audit- Production- } \\
\text { Governance }\end{array}$ \\
\hline Classification & Organic & Functional & Program & Functional \\
\hline Period & Short term & Long term & $\begin{array}{l}\text { Long term (3 Year } \\
\text { Forecast) }\end{array}$ & $\begin{array}{l}\text { Long term (5 Year } \\
\text { Forecast) }\end{array}$ \\
\hline Weightiness & Financial Balance & Efficiency & $\begin{array}{l}\text { Efficiency- } \\
\text { Effectiveness }\end{array}$ & $\begin{array}{l}\text { Economy- Efficiency- } \\
\text { Effectiveness }\end{array}$ \\
\hline $\begin{array}{l}\text { Application } \\
\text { Area }\end{array}$ & Public Sector & $\begin{array}{l}\text { Public - Private } \\
\text { Sector }\end{array}$ & $\begin{array}{l}\text { Public - Private } \\
\text { Sector }\end{array}$ & Public Sector \\
\hline
\end{tabular}

Source: Compiled by author 


\section{Conclusion}

The budget systems applied by the countries varries due to historical, economic, social, cultural and demographic differences. Similarly, the reasons behind a country's choose of a budget system, the scope, areas and principles of the budget are different. In this study, budget systems are dealt with under four headings and explained on the basis of the Turkish experience. According to the criteria of emergence date, budget systems are listed as the traditional budget system, performance budget system, program budget system and planning-programming budgeting system respectively. As the case of Turkey is conserned it seems that this ranking is not exactly followed.

When the data related to budget balance and budget system changes are evaluated together, there seems to be a remarkable parallelism between system changes and budget deficit. Similarly, there is an increase in extra-budgetary expenditures following the system changes. On the other hand, two major disadvantages caused by the increase in extra-budgetary expenditures should be noted. The first one is the fact that the expenditure control goes beyond the control of legislature which damages "budget rigt". The second is that the budget techniques remain out of practice.

There is no significant relationship between budget balance and macroeconomic variables.

\section{References}

Bülbül D., Ejder H.L. \& Şahan Ö. (2005). Devlet Bütçesi, Gazi Kitabevi, Baran Matbaası, Ağustos.

BÜMKO (2018). Statistics, Budget Size and Budget Realizations, Budget Expense and Income Realizations (1924-2018) http://www.bumko.gov.tr/TR,4461/butce-gider-gelirgerceklesmeleri-1924-2018.html (14.02.2018).

BÜMKO (2018). Budgeting in Turkey, http://www.bumko.gov.tr/TR,2518/turkiyede-butceleme. html (19.02.2019).

Edizdoğan N. (2004). Kamu Maliyesi, 8.Baskı, Bursa: Ekin Kitabevi.

OECD Data (2016). Investissement (FBCF), Turkey and OECD - Total https://data.oecd.org/fr/ gdp/investissement-fbcf.htm (19.02.2019)

OECD Data (2016). Gross domestic product (GDP), Turkey and OECD - Total https://data.oecd. org/gdp/gross-domestic-product-gdp.htm\#indicator-chart(19.02.2019)

Performance Budget, (2018). https://efinancemanagement.com/budgeting/performance-budget (14.02.2019).

Performance Budgeting in OECD Countries (2007) Part II Chapter 12 United Kingdom. ss.194 https://read.oecd-ilibrary.org/governance/performance-budgeting-in-oecdcountries_9789264034051-en\#page196 (18.02.2019)

Program Budget (2018). https://efinancemanagement.com/budgeting/program-budget (14.02.2019). 
Shah, A \& Shen, C. "A Primer On Performance Budgetting", (Anwar SHAH (Ed)), Budgeting and Budgetary Institutions, The World Bank Public Sector Governance and Accountability Series, 2007, ss.153 https://www.researchgate.net/publication/265231080 _A_Primer_on_Performance_Budgeting (18.02.2019).

TRG International (2009). How To Create An Advanced Budgeting System, Traditional budgeting approach: advantages and disadvantages https://cdn2.hubspot.net/hub/125873/file16819701-pdf/whitepapers/pm/wp_advancedbudgetingsystem_en.pdf (08.02.2019).

Tüğen K. (2007). Devlet Bütçesi (Gözden Geçirilmiş ve Genişletilmiş Altıncı Baskı), Bassaray Matbaası Çamdibi, İzmir.

TÜIKK, İşgücü İstatistikleri (2017). https://biruni.tuik.gov.tr/isgucuapp/isgucu.zul (20.02.2019).

Ursoiu, A.B. (2010). "The Advantages And Disadvantages Of The PPBES", Planning, Programming, Budgeting, Evaluation System-Benefits And Challenges, Bucharest,ss.101-109 http:// research.dresmara.ro/resurse/research/workshop2\%202010/workshop\%20PPBS.pdf (15.02.2019). 